\title{
Briquettes Produced With a Mixture of Urban Pruning Waste, Glycerin and Cassava Processing Residue
}

\author{
Silvia Maccari Petricoski ${ }^{1}$, Armin Feiden ${ }^{1}$, Adriana Ferla de Oliveira ${ }^{2}$, Luciene Kazue Tokura ${ }^{1}$, \\ Jair Antonio Cruz Siqueira ${ }^{1}$, Gabriela Bonassa ${ }^{1}$, Bruno Meneghel Zilli ${ }^{1}$, Daniele Patricia Gentelini-Marquez ${ }^{3}$, \\ Samuel Nelson Melegari de Souza ${ }^{1}$, Cristiano Alexandre Feiden ${ }^{4}$, Eduardo Augusto Feiden ${ }^{5}$ \\ $\&$ Alexandra da Silva Martinez ${ }^{6}$ \\ ${ }^{1}$ Post-Graduation Program in Engineering of Energy in Agriculture, State University of West Paraná, Cascavel, \\ Paraná, Brazil \\ ${ }^{2}$ Post-Graduation in Bioenergy, Federal University of Paraná, Palotina, Paraná, Brazil \\ ${ }^{3}$ UNOPAR, Campus Lago, Cascavel, Paraná, Brazil \\ ${ }^{4}$ Company Aurobindo, Den Haag, Netherlands \\ ${ }^{5}$ Company LBC Rotterdam, Rotterdam, Netherlands \\ ${ }^{6}$ State Center for Professional Education Manoel Moreira Pena, Paraná, Brazil \\ Correspondence: Luciene Kazue Tokura, Post-Graduation Program, State University of West Paraná, Street \\ Universitária, 2069-Jardim Universitário, CEP: 85819-110, Cascavel, Paraná, Brazil. Tel: 55-(45)-3220-3151. \\ E-mail: lucienetokura@gmail.com
}

Received: February 21, 2020

Accepted: April 29, $2020 \quad$ Online Published: May 15, 2020

doi:10.5539/jas.v12n6p158

URL: https://doi.org/10.5539/jas.v12n6p158

\begin{abstract}
The briquette is considered a solid biofuel, made from the compaction of lignocellulosic residues used for the generation of energy. This work aimed to study the production of briquettes from mixtures of Urban Pruning Waste (RPU) (pruning of leaves and thin branches of trees), glycerin and cassava bagasse (Manihot esculenta). Samples of RPU, cassava bagasse and glycerol were mixed to yield treatments T1 (100\% RPU), T2 (92\% RPU and $8 \%$ cassava bagasse), T3 (97\% RPU and 3\% glycerin), T4 (89\% RPU, $8 \%$ cassava bagasse and 3\% Glycerin), T5 (94.5\% RPU, 4\% cassava bagasse and 1.5\% glycerin) and T6 (control). Following this step, physical, chemical and energetic analyses (moisture content, volatile material content, fixed carbon and ash content, superior, inferior and useful calorific value, mechanical resistance, apparent and energetic density) of the briquettes were carried out. Treatment $\mathrm{T} 2$ had a lower fixed carbon value and volatile content, as well as higher ash content and mechanical strength. The percentages of carbon, hydrogen and nitrogen did not differ statistically between the treatments. The higher, lower and useful heating values were higher in treatment $\mathrm{T} 3$. The results showed that treatments $\mathrm{T} 1, \mathrm{~T} 2$ and $\mathrm{T} 3$ were more efficient, producing briquettes with properties that meet market specifications, besides presenting great energetic potential, being good substitutes for firewood.
\end{abstract}

Keywords: solid biofuel, biomass, bioenergy

\section{Introduction}

Among the impacts arising from the generation of waste, environmental waste is of great concern, os its ratem of generation is superior to that of degradation. Therefore, it is essential to reduce and reuse waste generated in agricultural, industrial and urban environments, aiming at recovering matter and energy, preserving natural resources and minimizing environmental damage (Galvão \& Oetterer, 2014).

Inappropriately discarded materials include those resulting from the pruning and removal of trees located in streets, avenues, flowerbeds, and squares. Due to the need to adapt to urban facilities, the lack of suitable facilities and high cost of their treatment, they comprise one of the main challenges faced by municipalities and electricity concessionaires in Brazilian municipalities (Baratta Jr \& Magalhães, 2010; Pari et al., 2017).

The inappropriate disposal of such waste in landfills or burning contributes to environmental degradation, although the appropriate management and application of byproducts of urban pruning in the production of 
wood-based materials have been considered environmentally sustainable, economically viable, and socially accepted (Nasser et al., 2016; Pérez et al., 2018).

Other agro-industrial wastes that are commonly disposed of incorrectly is the cassava (Manihot esculenta). The state of Paraná stands out as the second largest producer in the Brazilian rankings, with an estimated production of 2.79 million metric tons in the 2017 harvest (Companhia Nacional de Abastecimento [CONAB], 2017).

Although part of the national production of cassava is consumed in natura, a significant portion is used for industrial processing, as well as manufacture of flour, mainly generating solid residues, and starch, which provides greater production of liquid waste. The inadequate disposal of such waste poses serious environmental problems, which requires their management (Pandey et al., 2000; Leite et al., 2017).

The main crop waste and byproducts of cassava derived from industrial processes are composed of solid wastes, consisting mainly of husks, fibers and bagasse, as well as the liquid waste called manipueira and water from starch extraction (Versino et al., 2015).

Some byproducts are also generated in the production chain of biodiesel, such as glycerin, lecithin, bran, washing water, and oilcake. Crude glycerol consists mainly of glycerol (80\%) and lower amounts of soaps, water, alcohol, fatty acids, and salts, being co-produced during biodiesel synthesis and accounting for approximately $10 \%$ of the total weight of this biofuel (Haron et al., 2018; Khanday et al., 2017).

Glycerol is a chemical compound obtained as a co-product in the oleochemical industry, while glycerin is the name given to commercial blends that are rich in glycerol. Due to its unique combination of physical and chemical properties, glycerin has more than 1,500 final applications and is used as an ingredient or as a processing medium for cosmetics, hygiene and personal care products, medicines, and food products (Oliveira et al., 2013).

With the increasing demand for renewable energy sources and the establishment of the National Program for Biodiesel Production and Use (PNPB) in 2004 by the Federal Government, the production of biodiesel and, subsequently, glycerin has increased intensely in the country, resulting in an excess of supply with small demand for this product, as its use is not yet stabilized on the domestic fuel Market (Claudio et al., 2009).

Biodiesel is a mixture of long-chain methyl esters or ethyl esters, used in the partial or total replacement of fossil diesel. In Brazil, the National Agency for Petroleum, Natural Gas and Biofuels (ANP) regulates the percentage of biodiesel that should be mixed in diesel for marketing in the country. In 2008, the mandatory blend was $3 \%$; in 2010, it was 5\%; and currently, $8 \%$ (B8) are used. Simultaneously, the volume of glycerol produced in the country increases significantly, showing the need for adequate disposal and treatment for this purpose (Arad et al., 2017; Diário Oficial da União [DOU], 2016).

This surplus causes concern, as the glycerin manufactured as a byproduct of the biodiesel production process has a highly pollution potential. This byproduct is insoluble in rivers and lakes, and when in contact with them, precipitates in the water bodies, hampering the oxygenation of aquatic organisms. On the other hand, if used in the burning for heating purposes, it causes the emission of high concentrations of acrolein and acetaldehydes, which are highly toxic chemical compounds and carcinogens (Presciutti et al., 2017; Perales, et al., 2017).

With the aim of using this available waste for energy purposes, the purpose of this study was to produce briquettes from tree pruning waste (leaves and thin branches), glycerin and cassava processing waste, as an alternative for the generation of renewable energy, thus contributing to the reduction of environmental impacts and providing an alternative for the management of the large volume in which they are produced. The present study has a differential, since the three residues are studied together and not separately.

\section{Material and Methods}

\subsection{Collection, Drying and Packaging of Materials}

About $600 \mathrm{~kg}$ of Urban Pruning Waste (RPU) (pruning of leaves and thin branches of trees) were collected in the municipality of Vera Cruz do Oeste, located in the western region of the state of Paraná, with a latitude of $25^{\circ} 03^{\prime} 28^{\prime \prime} \mathrm{S}$, longitude 5352'37" W, and an altitude of $560 \mathrm{~m}$.

In addition, $700 \mathrm{~kg}$ of cassava processing waste (bagasse) from the Starch Processing Unit of Cooperativa Agroindustrial Lar, installed in the Municipality of Missal, PR, with a latitude $25^{\circ} 05^{\prime} 31^{\prime \prime} \mathrm{S}$, longitude of $54^{\circ} 14^{\prime} 51^{\prime \prime} \mathrm{W}$ and an altitude of $328 \mathrm{~m}$.

The residual glycerin resulting from the process of biodiesel production by methyl route and basic catalysis (about $8 \mathrm{~kg}$ ) was collected at the Federal University of Paraná (UFPR), located in the Municipality of Palotina, $\mathrm{PR}$, with a latitude $24^{\circ} 17^{\prime} 02^{\prime \prime} \mathrm{S}$, longitude of $53^{\circ} 50^{\prime} 24^{\prime \prime} \mathrm{W}$, and an altitude of $333 \mathrm{~m}$. 
The RPU samples were ground in a tree crusher (Ecológica brand, model PGM-400) with a stationary diesel engine drive of 54-67 hp, so that the particle size of the particles was 5-10 $\mathrm{mm}$.

For the drying of the RPU and cassava bagasse samples, a container-type dryer with forced circulation of air heated via solar energy, located in the Municipality of Vera Cruz do Oeste, PR, with temperature ranging from $20^{\circ} \mathrm{C}$ to $30^{\circ} \mathrm{C}$, was used (Figure 1 ).
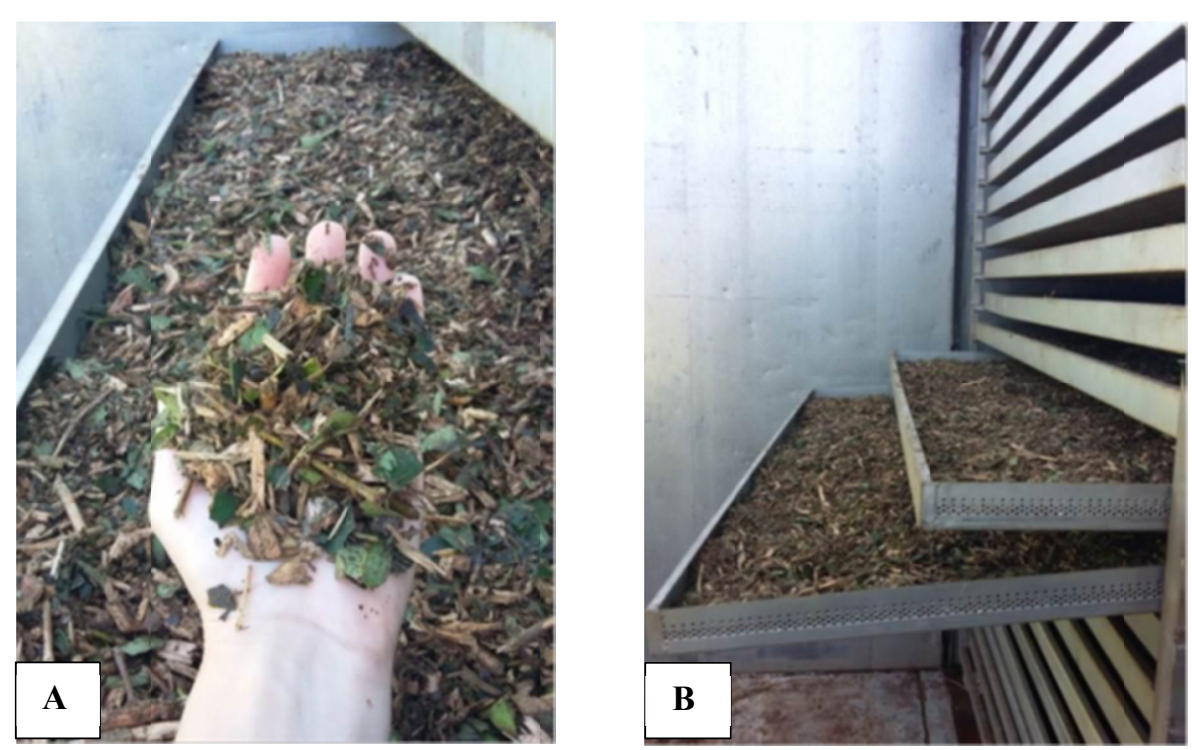

Figure 1. Residues from urban pruning. A: Crushed material. B: Crushed material from leaves and thin branches of trees in the dryer

The cassava bagasse, due to the high moisture, was placed in cloth bags and centrifuged in a domestic centrifuge to remove excess water. Thereafter, the material was sieved and dried in the dryer described above with a temperature also varying between $20^{\circ} \mathrm{C}$ and $30^{\circ} \mathrm{C}$ (Figure 2).
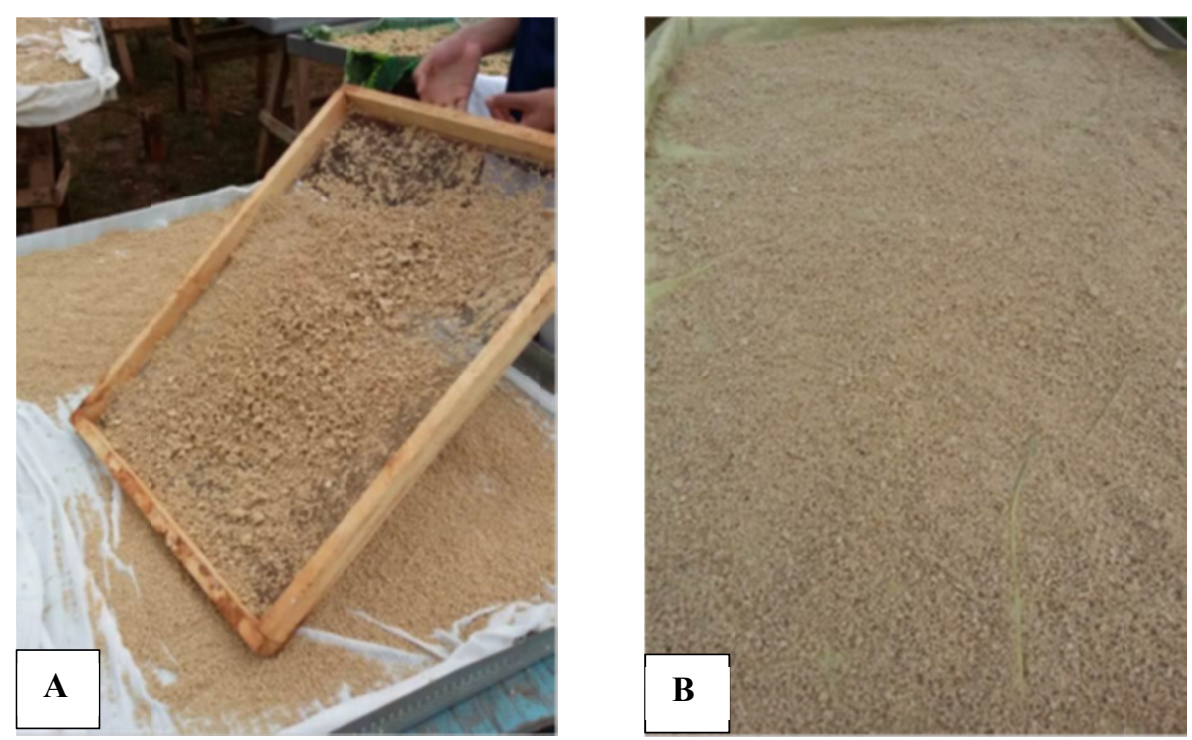

Figure 2. Cassava bagasse. A: Sieved material. B: Dry material

The masses of the RPU and cassava bagasse samples were determined using a platform scale (Toledo brand, model 2124/3), with a variation of $\pm 0.05 \mathrm{~kg}$. 
The RPU and cassava bagasse samples were kept for 30 days in the dryer until reaching the desired moisture content of $15-20 \%$ (Gonçalves et al., 2009). To verify the moisture, the masses were measured in the platform scale, in two trays. The procedure was repeated until a constant mass of the materials was obtained.

\subsection{Physical, Chemical and Energetic Characterization}

The moisture content of the RPU and cassava bagasse samples was tested at the Soil Physics Laboratory (LAFIS) of UNIOESTE, Cascavel campus, according to the Brazilian Association of Technical Standards (ABNT, 1983).

After drying and moisture determination, the materials (RPU and cassava bagasse) were packed in plastic bags coated with cardboard, to be transported to the company LENECO-Lenha Ecológica, located at BR Access Highway to road PRC 163, km 1, in the Rural Area of the Municipality of Capitão Leônidas Marques, PR, to undergo the briquetting process.

The determination of the moisture content for glycerin was carried out using the same methodology as for the other materials, being conducted in the Biofuel Production Laboratory (LPB) of UFPR, Palotina sector.

Based on the moisture analysis, it was verified that the glycerin had a content of $4 \%$, and there was no need for drying.

For the analysis of the sodium hydroxide contained in the glycerin, the methodology of the Adolfo Lutz Institute was applied, consisting of calcination followed by titration (Instituto Adolfo Lutz, 2008). The analysis was carried out in the Analytical Chemistry Laboratory of UNIOESTE, Toledo campus, where the hydroxide concentration identified in the glycerin was $7.0810^{-6} \mathrm{~mol} \mathrm{~L}^{-1}$.

\subsection{Production of the Briquettes}

To produce the briquettes, the RPU, cassava bagasse and glycerin samples were used in the proportions proposed for the briquetting, according to the specifications of the trials contained in Table 1. The complete experimental planning was performed.

Table 1. Briquette testing plan according to the mass and percentage composition of the wastes with three replicates. Vera Cruz do Oeste, 2016

\begin{tabular}{llll}
\hline Trial & Urban Pruning Waste (\%) & Cassava Bagasse (\%) & Glycerin (\%) \\
\hline T1 & 100.0 & - & - \\
T2 & 92.0 & 8 & - \\
T3 & 97.0 & - & 3.0 \\
T4 & 89.0 & 8 & 3.0 \\
T5 (Central Point) & 94.5 & 4 & 1.5 \\
T6 (Control) & 0 & - & - \\
\hline
\end{tabular}

For the production of the briquettes, the different concentrations of each waste were mixed manually and submitted to a mechanical piston briquette press for biomass (LIPPEL brand, model BL 95/210, power $55 \mathrm{~kW}$, year 2010), with a production capacity of $1,200-1,800 \mathrm{~kg} \mathrm{~h}^{-1}$, depending on the type of biomass used as raw material.

Each treatment was conducted in a unitary manner, with the residues inserted manually in the upper part of the briquette press. The biomass was compacted at a pressure of $48.94 \mathrm{kgf} \mathrm{cm}^{-2}$, reaching an internal temperature of $250^{\circ} \mathrm{C}$.

\subsection{Methods for Analyzing the Briquettes}

The analysis of the moisture content of the different briquettes was also conducted according to the technical standard established by ABNT (1983).

The methodology proposed by Sánchez (2010) was followed for the immediate analysis of the briquettes, with the quantification of the contents of volatile materials, ashes, and fixed carbon. The analyses were carried out in triplicate in the Organic Chemistry Laboratory of UFPR, Palotina sector.

To determine the percentages of carbon, hydrogen and nitrogen (elemental analysis), the samples of each treatment were sent to the Analytical Center of the Institute of Chemistry of the University of São Paulo (USP). They were subjected to combustion in an atmosphere of pure oxygen, and the gases resulting from this 
combustion were quantified in a TCD (thermal conductivity detector) by the Pregl-Dumas method in a CHN analyzer (Perkin Elmer 2400 series II).

The of higher heating value (HHV) was determined, according to NBR 8633 (ABNT, 1984), in the briquettes formed with the various concentrations of waste. To do this, the samples were previously dried, weighed in a digital scale (Marte brand, model AY220) and then coupled in a calorimetric pump (DDS brand, E2K model) to determine the higher heating value (Figure 3). These analyses were carried out in triplicate at the Soil Physics Laboratory (LAFIS) of UNIOESTE, Cascavel campus.
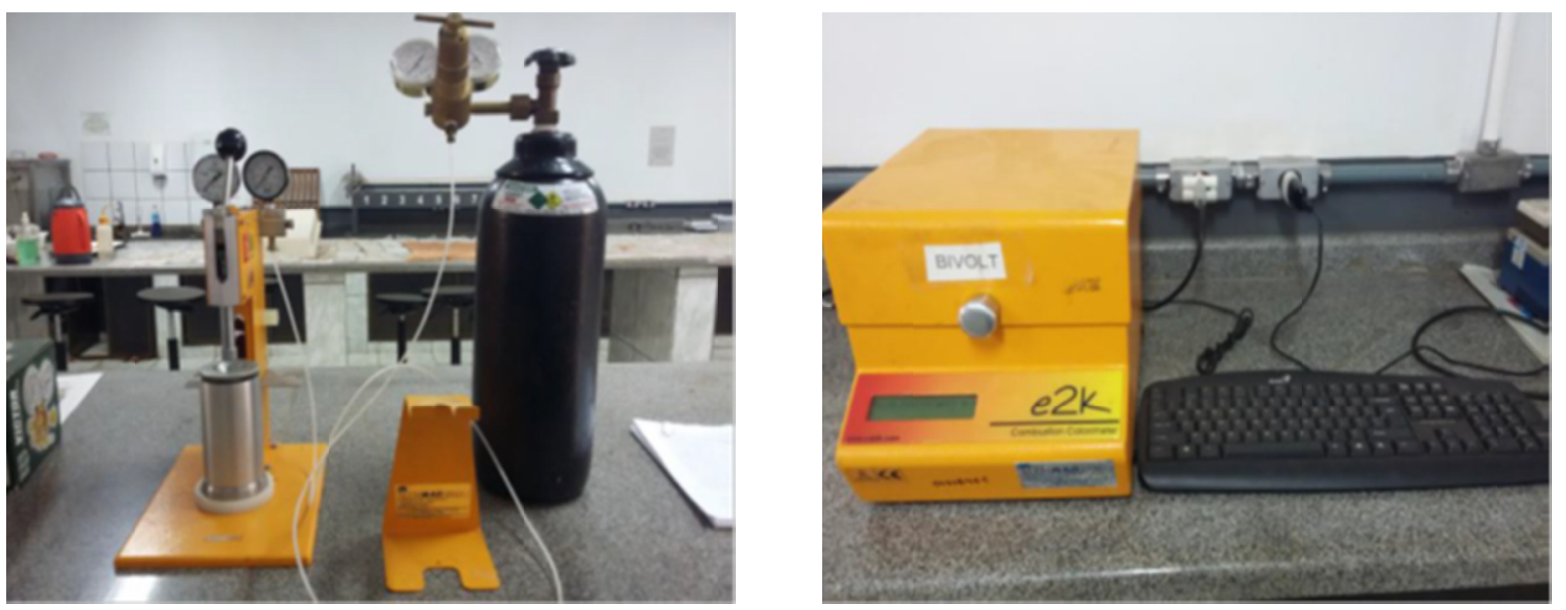

Figure 3. Calorimetric pump used in the analysis of the superior calorific power

In order to transform the HHV to LHV (lower heating value), Equation 1, as described by Brito (1986), was used:

$$
\mathrm{LHV}=\mathrm{HHV}-600(9 \mathrm{H} / 1)
$$

Where, LHV: lower heating value $\left(\mathrm{kcal} \mathrm{kg}^{-1}\right)$; HHV: higher heating value $\left(\mathrm{kcal} \mathrm{kg}^{-1}\right)$; $\mathrm{H}$ : hydrogen content (\%); 600: heat of condensation of water at $0{ }^{\circ} \mathrm{C} ; 9$ : amount of water (in kilograms) that is formed by oxidizing one kilogram of hydrogen.

To determine the useful heating value (UHV), Equation 2 (Gonçalves et al., 2009; Vale et al., 2007) was used.

$$
\mathrm{UHV}=[\mathrm{HHV}-\mathrm{K} \times(1-\mathrm{MC})-(600 \times \mathrm{MC})] / 238.89)
$$

Where, UHV: useful heating value $\left(\mathrm{kcal} \mathrm{kg}^{-1}\right)$; HHV: higher heating value $\left(\mathrm{kcal} \mathrm{kg}^{-1}\right)$; $\mathrm{K}$ : constant of heat of vaporization of water in the calorimeter, in the value of $324 \mathrm{kcal} \mathrm{kg}^{-1} ; 600$ : heat of condensation of water at $0{ }^{\circ} \mathrm{C}$; 238.89: transformation of kcal kg${ }^{-1}$ into $\mathrm{MJ} \mathrm{kg}^{-1}$ or $\mathrm{GJ} \mathrm{t}^{-1}$; $\mathrm{MC}$ : moisture content.

NBR 5739 (ABNT, 2007) was followed to evaluate the Ultimate Tensile Strength (UTS, kgf) of the briquettes. The analysis was carried out in the Laboratory of Engineering Structures and Materials (LEME) of UNIOESTE, Cascavel campus. To ensure greater uniformity of the surface of the briquettes, they were placed in molds and filled with molten sulfur before being submitted to the analysis.

The equipment used was a hydraulic press of the EMIC brand, model PC100, with capacity for 100 metric tons. The machine was programmed to work with the unit in kgf. The analyses were performed in triplicate.

The apparent density $\left(\mathrm{kg} \mathrm{m}^{-3}\right)$ of the briquettes was determined by the stereometric method (Protásio et al., 2011). The volume was calculated considering the cylindrical shape of the briquettes, and a digital caliper (King Tools brand, model Caliper, 0-150 mm) was used to determine the length and diameter, while the mass was obtained on a digital scale (Mark Shimadzu brand, model BL 3200H).

The energy density of the briquettes was calculated by multiplying the higher heating value by their apparent density values (Protásio et al., 2011).

\subsection{Statistical Analysis}

The experimental design was a completely randomized design involving a complete factorial planning, including the central point. With that, six (6) treatments were defined based on the variation of the amount of tree pruning waste, cassava bagasse and glycerin in the composition of the briquettes. 
The analyses were carried out with six (6) treatments and three (3) replicates, with moisture content, immediate analysis (volatile content, ash, and fixed carbon), elemental analysis (determination of $\mathrm{C}, \mathrm{H}$, and $\mathrm{N}$ ), heating value, apparent and energy density and mechanical strength of the briquettes being evaluated as variables.

The results of the analyses were calculated by non-parametric statistics and by comparing means using the Kruskal-Wallis test at the $5 \%$ error probability level, using the software program $\mathrm{R}$ and the additional supplement agricolae, obtaining means with the proper ranking (R Core Team, 2017; Mendiburu, 2016).

\section{Results}

The mean moisture values along with their standard deviations for each of the treatments can be seen in Table 2 .

Table 2. Mean moisture content values before briquetting, in the briquettes, and standard deviation. Cascavel, 2016

\begin{tabular}{llll}
\hline Treatment & Moisture content before briquetting (\%) & Moisture content of the briquettes (\%) & Standard deviation of the briquettes \\
\hline T1 & $8.632(\mathrm{a})$ & $7.935(\mathrm{a})$ & 0.168 \\
T2 & $8.771(\mathrm{a})$ & $8.308(\mathrm{~b})$ & 0.048 \\
T3 & $9.134(\mathrm{a})$ & $8.252(\mathrm{~b})$ & 0.107 \\
T4 & $9.119(\mathrm{a})$ & $8.775(\mathrm{~d})$ & 0.054 \\
T5 & 9.269 (a) & 8.667 (c) & 0.045 \\
\hline
\end{tabular}

Note. Equal letters indicate significantly equal values in the Kruskal-Wallis test at a 5\% error probability.

By applying the Kruskal-Wallis test at a 5\% probability of error, it can be concluded that the mean values of the moisture content before the briquetting did not differ statistically between them, as can be observed in Table 2 . Given that, the moisture was statistically equal for both materials.

Nevertheless, after obtaining the briquettes, it is observed that treatments T1, T4 and T5 differ from the others and with each other, while $\mathrm{T} 2$ and $\mathrm{T} 3$ are statistically equal to each other.

The briquettes were also submitted to immediate analysis (determination of the volatile content, fixed carbon, and ash content). The results can be seen in Table 3 .

Table 3. Mean values of the immediate analysis. Cascavel, 2016

\begin{tabular}{llll}
\hline Treatment & Volatile content (\%) & Fixed carbon content $(\%)$ & Ash content (\%) \\
\hline T1 & $70.959(\mathrm{c})$ & $20.231(\mathrm{a})$ & $8.808(\mathrm{~d})$ \\
T2 & $66.520(\mathrm{~d})$ & $16.858(\mathrm{c})$ & $16.621(\mathrm{e})$ \\
T3 & $72.483(\mathrm{~b})$ & $19.263(\mathrm{~b})$ & $8.253(\mathrm{c})$ \\
T4 & $72.962(\mathrm{~b})$ & $19.206(\mathrm{~b})$ & $7.831(\mathrm{~b})$ \\
T5 & 73.857 (a) & $20.110(\mathrm{a})$ & $6.032(\mathrm{a})$ \\
\hline
\end{tabular}

Note. Equal letters indicate significantly equal values in the Kruskal-Wallis test at a 5\% error probability.

Applying the Kruskal-Wallis test to a 5\% probability of error, it can be concluded that treatment $\mathrm{T} 2$ had the lowest volatile content value (66.520\%) fixed carbon value (16.858\%). On the other hand, it had the highest ash content value (16.621\%), differing statistically from the other treatments (Table 3 ).

The briquettes were then subjected to elemental analysis to determine the percentages of $\mathrm{C}, \mathrm{H}$ and $\mathrm{N}$, the results being shown in Table 4.

Table 4. Mean values of the elemental analysis. Cascavel, 2016

\begin{tabular}{llll}
\hline Treatment & $\mathrm{C}(\%)$ & $\mathrm{H}(\%)$ & $\mathrm{N}(\%)$ \\
\hline T1 & $45.01(\mathrm{a})$ & $6.12(\mathrm{a})$ & $1.53(\mathrm{a})$ \\
T2 & $45.33(\mathrm{a})$ & $6.30(\mathrm{a})$ & $1.77(\mathrm{a})$ \\
T3 & $46.48(\mathrm{a})$ & $6.61(\mathrm{a})$ & $1.57(\mathrm{a})$ \\
T4 & $46.00(\mathrm{a})$ & $6.27(\mathrm{a})$ & $1.22(\mathrm{a})$ \\
T5 & 46.93 (a) & $6.83(\mathrm{a})$ & $1.44(\mathrm{a})$ \\
\hline
\end{tabular}

Note. Equal letters indicate significantly equal values in the Kruskal-Wallis test at a $5 \%$ error probability. 
It is observed in Table 4 that the percentages of $\mathrm{C}, \mathrm{H}$ and $\mathrm{N}$ of the treatments did not differ significantly from each other, and that the amount of glycerin used in this work in treatments T3, T4 and T5 did not change the C/H ratio.

The values of the higher heating value of the briquettes are shown in Table 5 .

Table 5. Mean values of the higher heating value and standard deviation. Cascavel, 2016

\begin{tabular}{lll}
\hline Treatment & Higher heating value $\left(\mathrm{MJ} \mathrm{kg}^{-1}\right)$ & Standard deviation \\
\hline T1 & $17.549(\mathrm{c})$ & 0.499 \\
T2 & $16.229(\mathrm{~d})$ & 0.163 \\
T3 & $18.973(\mathrm{a})$ & 0.467 \\
T4 & $17.528(\mathrm{c})$ & 0.178 \\
T5 & 18.437 (b) & 0.106 \\
\hline
\end{tabular}

Note. Equal letters indicate significantly equal values in the Kruskal-Wallis test at a 5\% error probability.

By applying the Kruskal-Wallis test at a 5\% probability of error, it can be concluded that the mean values of the higher heating value were statistically different for the treatments.

With the values of the $\mathrm{H}$ content determined by the elemental analysis, as well as the moisture content of the briquettes, by applying the equations 2 and 3, it is possible to obtain the value of the lower and useful heating value (Table 6).

Table 6. Mean lower and useful heating value. Cascavel, 2016

\begin{tabular}{lll}
\hline Treatment & Lower heating value $\left(\mathrm{MJ} \mathrm{kg}^{-1}\right)$ & Useful heating value $\left(\mathrm{MJ} \mathrm{kg}^{-1}\right)$ \\
\hline T1 & $16.165(\mathrm{c})$ & $14.731(\mathrm{c})$ \\
T2 & $14.806(\mathrm{~d})$ & 13.449 (d) \\
T3 & $17.480(\mathrm{a})$ & 15.980 (a) \\
T4 & 16.110 (c) & 14.555 (c) \\
T5 & 16.893 (b) & $15.406(\mathrm{~b})$ \\
\hline
\end{tabular}

Note. Equal letters indicate significantly equal values in the Kruskal-Wallis test at a 5\% error probability.

It is observed in Table 6 that, in relation to the LHV and UHV of the briquettes synthesized from the different treatments, they differed statistically among themselves at a $5 \%$ probability level.

The mean values of apparent and energy density of the briquettes are presented in Table 7.

Table 7. Mean values of apparent density, energy density, and standard deviation. Cascavel, 2016

\begin{tabular}{llll}
\hline Treatment & Apparent density $\left(\mathrm{kg} \mathrm{m}^{-3}\right)$ & Apparent density $\left(\mathrm{MJ} \mathrm{m}^{-3}\right)$ & Standard deviation for energy density \\
\hline T1 & $1,183.00(\mathrm{a})$ & $20,778.76(\mathrm{a})$ & $1,254.31$ \\
T2 & $1,116.00(\mathrm{a})$ & $18,122.70(\mathrm{~b})$ & $1,165.89$ \\
T3 & $925.00(\mathrm{~b})$ & $17,472.43(\mathrm{~b})$ & 249.27 \\
T4 & Not measured & Not measured & Not measured \\
T5 & Not measured & Not measured & Not measured \\
\hline
\end{tabular}

Note. Equal letters indicate significantly equal values in the Kruskal-Wallis test at a 5\% error probability.

The briquettes of treatments 4 and 5 did not support the movements caused by the transportation from its production to the Soil Physics Laboratory (LAFIS) of UNIOESTE, Cascavel campus, and it was not possible to evaluate the apparent and energy density values.

For the other treatments, by applying the Kruskal-Wallis test at a 5\% probability of error, it can be concluded that the mean apparent density values of treatments $\mathrm{T} 1$ and $\mathrm{T} 2$ did not differ statistically from each other. It can also be noted in Table 7 that treatment T3 $\left(925 \mathrm{~kg} \mathrm{~m}^{-3}\right)$ obtained the lowest value of energy density. 
According to the Kruskal-Wallis test at a 5\% probability of error, that mean energy density values were statistically the same for T2 $\left(18,122.70 \mathrm{MJ} \mathrm{m}^{-3}\right)$ and $\mathrm{T} 3\left(17,472.43 \mathrm{MJ} \mathrm{m}^{-3}\right)$, which were different from treatment $\mathrm{T} 1\left(20,778.76 \mathrm{MJ} \mathrm{m}^{-3}\right)$, as can be seen in Table 7.

It is also observed that treatment $\mathrm{T} 1$ presents the highest mean energy density value $\left(20,778.76 \mathrm{MJ} \mathrm{m}^{-3}\right)$, due to the high apparent density of the briquettes, when compared to treatments $\mathrm{T} 2\left(18,122.70 \mathrm{MJ} \mathrm{m}^{-3}\right)$ and $\mathrm{T} 3$ $\left(17,472.43 \mathrm{MJ} \mathrm{m}^{-3}\right)$, a factor which provides high energy density.

Afterwards, the briquettes were submitted to the mechanical strength analysis through the ultimate tensile strength. The results can be seen in Table 8 .

Table 8. Mean values of mechanical strength and standard deviation. Cascavel, 2016

\begin{tabular}{lll}
\hline Treatment & Mechanical strength $\left(\mathrm{kgf} \mathrm{cm}^{-2}\right)$ & Standard deviation \\
\hline T1 & $1.111(\mathrm{ab})$ & 0.239 \\
T2 & $1.281(\mathrm{a})$ & 0.097 \\
T3 & $0.869(\mathrm{~b})$ & 0.058 \\
T4 & Not measured & Not measured \\
T5 & Not measured & Not measured \\
\hline
\end{tabular}

Note. Equal letters indicate significantly equal values in the Kruskal-Wallis test at a 5\% error probability.

By applying the Kruskal-Wallis test at a 5\% probability of error, it can be concluded that the mean mechanical strength values were statistically different for treatments T2 $\left(1.281 \mathrm{kgf} \mathrm{cm}^{-2}\right)$ and T3 $\left(0.869 \mathrm{kgf} \mathrm{cm}^{-2}\right)$ (Table 8).

Treatment T2 $\left(1.281 \mathrm{kgf} \mathrm{cm}^{-2}\right)$ presented a higher mechanical strength value. This can be justified by the addition of $8 \%$ of the cassava bagasse, which serves as a particle binder thanks to the starch, which gives greater mechanical strength to the briquettes.

\section{Discussion}

The use of glycerol as a material for obtaining briquettes provided a higher moisture content for them, as shown in Table 2. Treatments T4 and T5 with higher initial concentrations thereof had higher moisture contents. This comes from the hygroscopic characteristic of glycerol, which absorbs moisture from the air (Okoye et al., 2016).

Mean values of the moisture content after briquetting differed statistically from each other. The moisture content was lower in the briquette of treatment T1 (7.935\%) and higher in the briquette of treatment T4 (8.775\%).

Yank et al. (2016), when producing bark and rice bran briquettes, obtained a moisture content varying between $4.64 \%$ and $7.42 \%$ for the briquettes. In turn, Soares et al. (2015) determined the moisture content for briquettes produced with $40 \%$ wood sawdust and $60 \%$ coffee grounds with a moisture content of $8.99 \%$. The moisture content values of the briquettes obtained in this study were within the ranges mentioned.

The use of cassava bagasse contributed to the increased inorganic material in the briquette, thus reducing the calorific value. These values may also be associated to a large amount of impurities adhered to the cassava bagasse, such as earth, sand, and other inert materials.

It can be observed in Table 3 that treatment T5 had higher contents of volatile materials ( $73.857 \%)$. In contrast, the ash content values were lower $(6.032 \%)$, as glycerin facilitates the combustion of the material and raises temperature in a short time. The same was observed through the high HHV.

Nakashima et al. (2017) and Dias-Júnior (2016) present in their studies ash, volatile and fixed carbon content values for briquettes produced from different biomasses, and the values obtained in this experiment for briquettes with different concentrations of glycerol, cassava bagasse and tree pruning waste are close to those mentioned by the authors.

According to Embrapa (2002), the apparent density of the briquettes in Brazil varies from 1,000 $\mathrm{kg} \mathrm{m}^{-3}$ to 1,300 $\mathrm{kg} \mathrm{m}^{-3}$, so the values obtained for them are within the range mentioned.

Pimenta et al. (2015), when producing briquettes from coconut shell coal, reached apparent density values of 660 $\mathrm{kg} \mathrm{m}^{-3}$ and $710 \mathrm{~kg} \mathrm{~m}^{-3}$ in treatments $12 / 12$ and $12 / 15$ for the proportion of starch and clay used as a binder in relation to the total dry weight of the briquettes, respectively.

The average values for apparent and energy density of the waste briquettes of the processing of coffee beans submitted to the carbonization processes; roasting at a rate of $1.5{ }^{\circ} \mathrm{C} \mathrm{min}{ }^{-1}$ and $3.0^{\circ} \mathrm{C} \min ^{-1}$ and in natura were 
$793 \mathrm{~kg} \mathrm{~m}^{-3}$ and 22,800 $\mathrm{MJ} \mathrm{m}^{-3}$ for the carbonization process; $866 \mathrm{~kg} \mathrm{~m}^{-3}$ and 20,600 $\mathrm{MJ} \mathrm{m}^{-3}$ for roasting at a rate of $1.5^{\circ} \mathrm{C} \mathrm{min}^{-1} ; 855 \mathrm{~kg} \mathrm{~m}^{-3}$ and $20,100 \mathrm{MJ} \mathrm{m}^{-3}$ for roasting at a rate of $3.0^{\circ} \mathrm{C} \mathrm{min}^{-1}$; and $1,292 \mathrm{~kg} \mathrm{~m}^{-3}$ and 23,500 $\mathrm{MJ} \mathrm{m}^{-3}$ for the in natura briquette, respectively (Protásio et al., 2012).

Chen et al. (2011) obtained the values of $66.73 \%, 5.84 \%, 27.30 \%$ and $0.14 \%$ for carbon, hydrogen, oxygen, and nitrogen, respectively.

Treatment T3 (18.973 $\mathrm{MJ} \mathrm{kg}^{-1}$ ) had the highest heating value when compared to the other tests. According to Anitha et al. (2016), glycerol has a high heating value (between 13-22 $\mathrm{MJ} \mathrm{kg}^{-1}$ ), and the addition of glycerol in the synthesis of briquettes provided an increase in this variable.

Treatment $\mathrm{T} 2\left(16,229 \mathrm{MJ} \mathrm{kg}^{-1}\right)$ presented a lower heating value, differing statistically from the other treatments. In this treatment, a higher concentration of cassava bagasse was applied, and according to the literature (Polachini et al., 2016; Lubwama, \& Yiga, 2017), this material presents high moisture, which gives a lower heating value for this waste. It is also mentioned that an alternative to this disadvantage would be the carbonization of the cassava bagasse prior to use for the synthesis of briquettes (increase from $16 \mathrm{MJ} \mathrm{MJ} \mathrm{kg}{ }^{-1}$ to $\left.22.5 \mathrm{MJ} \mathrm{kg}^{-1}\right)$.

Yank et al. (2016), when producing bark and rice bran briquettes, found higher heating values varying from $16.01 \mathrm{MJ} \mathrm{kg}^{-1}$ to $16.45 \mathrm{MJ} \mathrm{kg}^{-1}$, close to those obtained in this study.

Sakkampang and Wongwuttanasatian (2014) also used glycerol as a material for the synthesis of briquettes, albeit with sawdust and sugarcane bagasse, obtaining values of $15-18 \mathrm{MJ} \mathrm{kg}^{-1}$, similar to those obtained for glycerol briquettes, cassava bagasse, and pruning waste.

Therefore, the higher heating value (HHV) obtained in this study are in agreement with the literature and present good results related to the heating value. Thus, higher heating value (HHV) results favor the reutilization of urban pruning waste, glycerin and cassava processing waste thanks to the energy potential of the briquettes.

Waste-to-energy technologies provide synergy between managing waste produced in large quantities and requiring treatment due to environmental impacts along with obtaining a lower-cost energy source. Its advantages include the elimination and/or reduction of adverse effects of these wastes on public health, which provide safety to the environment, contribute to sustainability factors, and supply a new energy source, thereby reducing greenhouse gas emissions and reducing pollutants from the use of fossil fuels (Skaggs et al., 2017; Alisaraei-Taghizadeh et al., 2017).

Soares et al. (2015) determined the ultimate tensile strength of briquettes produced with $40 \%$ of wood sawdust and $60 \%$ of coffee grounds, with a mechanical strength of $2.54 \mathrm{kgf} \mathrm{cm}^{-2}$, higher than that found for the studied briquettes.

Protásio et al. (2012) obtained mechanical tensile strength values by diametrical compression of the briquettes produced of around $12.03 \mathrm{kgf} \mathrm{cm}^{-2}$ for in natura briquettes; $10.30 \mathrm{kgf} \mathrm{cm}^{-2}$ for briquettes roasted at a rate of $3.0^{\circ} \mathrm{C} \mathrm{min}^{-1} ; 9.79 \mathrm{kgf} \mathrm{cm}^{-2}$ for briquettes roasted at $1.5^{\circ} \mathrm{C} \mathrm{min}^{-1}$ and $3.97 \mathrm{kgf} \mathrm{cm}^{-2}$ for briquettes carbonized in the coffee bean processing study.

Regarding economic analysis, the Municipality of Vera Cruz do Oeste produced approximately $500 \mathrm{~m}^{3}$ of tree pruning waste on public roads.

If $6.5 \mathrm{~m}^{3}$ of urban pruning waste is equivalent to the production of 1 ton of briquettes, the Municipality would produce 76.92 tons of briquettes.

At a cost of $\mathrm{R} \$ 307.00 \mathrm{t}^{-1}$, urban pruning waste could generate an annual revenue of approximately $\mathrm{R} \$ 23,614.44$ to the municipality.

\section{Conclusion}

The treatment $\mathrm{T} 1$ showed a lower moisture content $(7.935 \%)$ of the briquettes after the briquetting;

In the immediate analysis, treatment $\mathrm{T} 2$ obtained a lower fixed carbon value (16.858\%) and volatile content (66.520\%), and a higher ash content (16.621\%);

In the elementary analysis, the percentages of $\mathrm{C}, \mathrm{H}$ and $\mathrm{N}$ did not differ statistically between treatments;

The upper, lower and useful calorific value were higher in treatment T3 $\left(18.973 \mathrm{MJ} \mathrm{kg}^{-1}\right) ;\left(17.480 \mathrm{MJ} \mathrm{kg}^{-1}\right)$ and (15.980 $\mathrm{MJ} \mathrm{kg}^{-1}$ ) respectively;

The apparent density was higher in treatments $\mathrm{T} 1\left(1,183 \mathrm{~kg} \mathrm{~m}^{-3}\right)$ and $\mathrm{T} 2\left(1,116 \mathrm{~kg} \mathrm{~m}^{-3}\right)$. The energy density was higher in Treatment $\mathrm{T} 1\left(20,778.76 \mathrm{MJ} \mathrm{m}^{-3}\right)$; 
Regarding mechanical resistance, the T2 treatment showed the highest value $\left(1.281 \mathrm{kgf} \mathrm{cm}^{-2}\right)$;

Treatments T1, T2 and T3 were the most efficient for the production of briquettes based on the data obtained in the immediate moisture, ash, volatile and fixed carbon content analysis, as well as apparent and energy density. Nevertheless, all treatments presented higher and lower results for the higher, lower and useful heating values, with higher values characterizing advantageous characteristics from the standpoint of energy.

\section{References}

ABNT (Associação Brasileira de Normas). (1983). Carvão mineral-Determinação de umidade (NBR 8293). Rio de Janeiro, Brazil. Retrieved from https:/www.normas.com.br/visualizar/abnt-nbr-nm/11904/abnt-nbr 16586-carvao-mineral-determinacao-do-teor-de-cinzas

ABNT (Associação Brasileira de Normas). (1984). Carvão vegetal-Determinação do poder calorífico (NBR8633). Rio de Janeiro, Brazil. Retrieved from https:/www.normas.com.br/visualizar/abnt-nbr-nm/ 5377/abnt-nbr6923-carvao-vegetal-amostragem-e-preparacao-da-amostra

ABNT (Associação Brasileira de Normas). (2007). Concreto-Ensaios de compressão de corpos-de-prova cilíndricos (NBR5739). Rio de Janeiro, Brazil. Retrieved from https://tuxdoc.com/download/nbr-57392018-concreto-ensaio-de-compressao-de-corpos-de-prova-cilindricos-4_pdf

Alisaraei-Taghizadeh, A, Assar, H. A., Ghobadian, B., \& Motevali, A. (2017). Potential of biofuel production from pistachio waste in Iran. Renewable and Sustainable Energy Reviews, 72, 510-522. https://doi.org/10.1016/j.rser.2017.01.111

Anitha, M., Kamarudin, S. K., \& Kofli, N. T. (2016). The potential of glycerol as a value-added commodity. Chemical Engineering Journal, 295, 119-130. https://doi.org/10.1016/j.cej.2016.03.012

Arad, A., Sher, E., \& Enden, G. (2017). Modeling soot formation in diesel-biodiesel flames. Fuel, $206,437-452$. https://doi.org/10.1016/j.fuel.2017.06.024

Baratta Jr, A. P., \& Magalhães, L. M. S. (2010). Use of waste from trees prunning in the city of Rio de Janeiro for organic compost production. Revista de Ciências Agroambientais, 8, 113-125. Retrieved from http://www.unemat.br/revistas/rcaa/docs/vol8/11_artigo_v8.pdf

Brito, J. O. (1986). Madeira para energia: A verdadeira realidade do uso de recursos florestais. Silvicultura, 41, 188-193.

Chen, W. H., Hsu, H. C., Lu, K. M., Lee, W. J., \& Lin, T. C. (2011). Thermal pretreatment of wood (Lauan) block by torrefaction and its influence on the properties of the biomass. Energy, 36, 3012-3021. https://doi.org/10.1016/j.energy.2011.02.045

Claudio, J. A. M., Silva, C. X., \& Gonçalves, V. C. (2009). Glycerochemistry: New products and processes from glycerin of biodiesel production. Quimica Nova, 32, 639-648. https://doi.org/10.1590/S0100-4042200900 0300008

CONAB (Companhia Nacional de Abastecimento). (2017). Raiz, Fécula e Farinha. Conjuntos da Agropecuária, Mandioca, Julho de 2017. Retrieved from https://www.conab.gov.br

Dias-Júnior, A. F., Andrade, A. M., Carvalho, A. M., Benício, E. L., \& Brito, J. O. (2016). Produção de briquetes de moinha de carvão vegetal e resíduos lignocelulósicos visando uso bioenergético. Scientia Forestalis, 44, 453-462. https://doi.org/10.18671/scifor.v44n110.18

DOU (Diário Oficial da União). (2016). Lei $N^{o}$ 13.263, de 23 de março de 2016: Percentuais de adição de biodiesel ao óleo diesel comercializado no território nacional. Retrieved from http://www.planalto.gov.br/ ccivil_03/_Ato2015-2018/2016/Lei/L13263.htm

EMBRAPA (Empresa Brasileira de Pesquisa Agropecuária). (2002). Resíduos. EMBRAPA, Brazil.

Galvão, J. A., \& Oetterer, M. (2014). Qualidade e Processamento do Pesado (p. 237). Elsevier: Rio de Janeiro.

Gonçalves, J. E., Sartori, M. M. P., \& Leão, A. L. (2009). Energy from briquettes produced from remains of urban solid residues and wood of Eucalyptus grandis. Revista Brasileira de Engenharia Agricola e Ambiental, 13, 657-661. https://doi.org/10.1590/S1415-43662009000500021

Haron, R., Mat, R., Abdullah, T. A. T., \& Rahman, R. A. (2018). Overview on utilization of biodiesel by-product for biohydrogen production. Journal of Cleaner Production, 172, 314-324. https://doi.org/10.1016/j.jclepro. 2017.10.160 
Instituto Adolfo Lutz. (2008). Métodos físico-químicos para análise de alimentos (p. 1020). São Paulo: Instituto Adolfo Lutz. Retrieved from www.ial.sp.gov.br/resources/editorinplace/ial/2016_3_19/analisedealimento sial_2008.pdf

Khanday, W. A., Okeye, P. U., \& Hameed, B. H. (2017). Biodiesel byproduct glycerol upgrading to glycerol carbonate over lithium-oil palm ash zeolite. Energy Conversion and Management, 151, 472-480. https://doi.org/10.1016/j.enconman.2017.08.091

Leite, A. L. M. P., Zanon, C. D., \& Menegalli, F. C. (2017). Isolation and characterization of cellulose nanofibers from cassava root bagasse and peelings. Carbohydrate Polymers, 157, 962-970. https://doi.org/10.1016/ j.carbpol.2016.10.048

Lubwama, M., \& Yiga, V. A. (2017). Development of groundnut shells and bagasse briquettes as sustainable fuel sources for domestic cooking applications in Uganda. Renewable Energy, 111, 532-542. https://doi.org/10.1016/j.renene.2017.04.041

Mendiburu, F. (2016). Agricolae: Statistical Procedures for Agricultural Research (R Package Version 1.2-4). Retrieved from https:/CRAN.R-project.org/package=agricolae

Nakashima, G. T., Adhmann, I. C. S., Hansted, A. L. S., Belini, G. B., Waldman, W. R., \& Yamaji, F. M. (2017). Lignocellulosic Materials: Characterization and Production of Briquettes. Revista Virtual de Química, 9 , 150-162. https://doi.org/10.21577/1984-6835

Nasser, R. A., Salem, M. Z. M., Al-Mefarrej, A. A., \& Ared, I. M. (2016). Use of tree pruning wastes for manufacturing of wood reinforced cement composites. Cement and Concrete Composites, 72, $246-256$. https://doi.org/10.1016/j.cemconcomp.2016.06.008

Okoye, P. U., Abdullah, A. Z., \& Hameed, B. H. (2016). Glycerol carbonate synthesis from glycerol and dimethyl carbonate using trisodium phosphate. Journal of the Taiwan Institute of Chemical Engineers, 68, 51-58. https://doi.org/10.1016/j.jtice.2016.09.011

Oliveira, J. S., Antoniassi, R., Freitas, S. C., \& Müller, M. D. (2013). Chemical composition of glycerin produced by biodiesel plants in Brazil and potential utilization in animal feeding. Ciência Rural, 43, 509-512. https://doi.org/10.1590/S0103-84782013000300022

Pandey, A., Soccol, C. R., Nigam, P., Soccol, V. T., Vandenberghe, P. S., \& Mohan. R. (2000). Biotechnological potential of agro-industrial residues. II: cassava bagasse. Bioresource Technology, 74, 81-87. https://doi.org/ 10.1016/S0960-8524(99)00143-1

Pari, L., Suardi, A., Santangelo, E., Galindo, D. G., Scarfone, A., \& Alfano, V. (2017). Current and innovative technologies for pruning harvesting: A review. Biomass and Bioenergy, 107, 398-410. https://doi.org/ 10.1016/j.biombioe.2017.09.014

Perales, E., García, J. I., Pires, E., Aldea, L., Lomba, L., \& Giner, B. (2017). Ecotoxicity and QSAR studies of glycerol ethers in Daphnia magna. Chemosphere, 183, 277-285. https://doi.org/10.1016/j.chemosphere. 2017.05.107

Pérez, A., Martín-Lara, M. A., Pérez-Galvez, A., Calero, M., \& Ronda, A. (2018). Kinetic analysis of pyrolysis and combustion of the olive tree pruning by chemical fractionation. Bioresource Technology, 249, 557-566. https://doi.org/10.1016/j.biortech.2017.10.045

Pimenta, A. S., Santos, R. C., Carneiro, A. C. O., \& Castro, R. V. O. (2015). Charcoal briquettes produced with recycled coconut pith. Ciência Florestal, 25, 137-144. https://doi.org/10.5902/1980509817471

Polachini, T. C., Betiol, L. F. L., Lopes-Filho, J. F., \& Telis-Romero, J. (2016). Water adsorption isotherms and thermodynamic properties of cassava bagasse. Thermochimica Acta, 632, 79-85. https://doi.org/10.1016/ j.tca.2016.03.032

Presciutti, A., Asdrubali, F., Baldinelli, G., Rotili, A., Malavasi, M., \& Salvia, G. D. (2017). Energy and exergy analysis of glycerol combustion in an innovative flameless power plant. Journal of Clean Production, 172, 3817-3824. https://doi.org/10.1016/j.jclepro.2017.06.022

Protásio, T. P., Alves, I. C. N.,Trugilho, P. F., Silva, V. O., \& Baliza, A. E. R. (2011). Compaction of plant biomass for solid biofuels production. Pesquisa Florestal Brasileira, 31, 273-283. https://doi.org/10.4336/ 2011.pfb.31.68.273 
Protásio, T. P., Bufalino, L., Mendes, R. F., Ribeiro, M. X., Trugilho, P. F., \& Leite, E. R. S. (2012).Torrefação e carbonização de briquetes de resíduos do processamento dos grãos de café. RevBraEngAgriAmb, 16, 1252-1258. https://doi.org/10.1590/S1415-43662012001100015

R Core Team. (2017). R: A Language and environment for statistical computing. R Foundation for Statistical Computing, Vienna, Austria. Retrieved from https://www.R-project.org

Sakkampang, C., \& Wongwuttanasatian, T. (2014). Study of ration of energy consumption and gained energy during briquetting process for glycerin-biomass briquette fuel. Fuel, 115, 186-189. https://oi.org/10.1016/ j.fuel.2013.07.023

Sánchez, C. G. (2010). Tecnologia da Gaseificação de biomassa (p. 432). Campinas: Átomo.

Skaggs, R. L., Coleman, A. M., Seiple, T. E., \& Milbrandt, A. R. (2017). Waste-to-Energy biofuel production potential for selected feedstocks in the conterminous United States. Renewable and Sustainable Energy Reviews, 82(3), 2640-2651. https://doi.org/10.1016/j.rser.2017.09.107

Soares, L. S., Moris, V. A. S., Yamaji, F. M., \& Paiva, J. M. F. (2015). Use of waste coffee grounds and sawdust in briquettes molding and evaluation of properties. Revista Matéria, 20(2), 550-560. https://doi.org/10.1590/ S1517-707620150002.0055

Vale, A. T., Gentil, L. V., Gonçalez, J. C., \& Costa, A. F. (2007). Caracterização energética e rendimento da carbonização de resíduos de grãos de café (Coffea arabica, L.) e de madeira (Cedrelinga catenaeforis). Cerne, 13(4), 416-420.

Versino, F., Lópes, O. V., \& García, M. A. (2015). Sustainable use of cassava (Manihot esculenta) roots as raw material for biocomposites development. Industrial Crops and Products, 65, 79-89. https://doi.org/10.1016/ j.indcrop.2014.11.054

Yank, A., Ngadi, M., \& Kok, R. (2016). Physical properties of rice husk and bran briquettes under low pressure densification for rural applications. Biomass and Bioenergy, 84, 22-30. https://doi.org/10.1016/j.biombioe. 2015.09.015

\section{Copyrights}

Copyright for this article is retained by the author(s), with first publication rights granted to the journal.

This is an open-access article distributed under the terms and conditions of the Creative Commons Attribution license (http://creativecommons.org/licenses/by/4.0/). 